\title{
Protein carbonylation in food and nutrition: a concise update
}

\author{
Mario Estévez ${ }^{1}\left[\right.$ Silvia Díaz-Velasco $^{1} \cdot$ Remigio Martínez $^{1}$
}

Received: 30 June 2021 / Accepted: 28 September 2021 / Published online: 20 October 2021

(c) The Author(s) 2021

\begin{abstract}
Protein oxidation is a topic of indisputable scientific interest given the impact of oxidized proteins on food quality and safety. Carbonylation is regarded as one of the most notable post-translational modifications in proteins and yet, this reaction and its consequences are poorly understood. From a mechanistic perspective, primary protein carbonyls (i.e. $\alpha$-aminoadipic and $\gamma$-glutamic semialdehydes) have been linked to radical-mediated oxidative stress, but recent studies emphasize the role alternative carbonylation pathways linked to the Maillard reaction. Secondary protein carbonyls are introduced in proteins via covalent linkage of lipid carbonyls (i.e. protein-bound malondialdehyde). The high reactivity of protein carbonyls in foods and other biological systems indicates the intricate chemistry of these species and urges further research to provide insight into these molecular mechanisms and pathways. In particular, protein carbonyls are involved in the formation of aberrant and dysfunctional protein aggregates, undergo further oxidation to yield carboxylic acids of biological relevance and establish interactions with other biomolecules such as oxidizing lipids and phytochemicals. From a methodological perspective, the routine dinitrophenylhydrazine (DNPH) method is criticized not only for the lack of accuracy and consistency but also authors typically perform a poor interpretation of DNPH results, which leads to misleading conclusions. From a practical perspective, the biological relevance of protein carbonyls in the field of food science and nutrition is still a topic of debate. Though the implication of carbonylation on impaired protein functionality and poor protein digestibility is generally recognized, the underlying mechanism of such connections requires further clarification. From a medical perspective, protein carbonyls are highlighted as markers of protein oxidation, oxidative stress and disease. Yet, the specific role of specific protein carbonyls in the onset of particular biological impairments needs further investigations. Recent studies indicates that regardless of the origin (in vivo or dietary) protein carbonyls may act as signalling molecules which activate not only the endogenous antioxidant defences but also implicate the immune system. The present paper concisely reviews the most recent advances in this topic to identify, when applicable, potential fields of interest for future studies.
\end{abstract}

Keywords Protein carbonylation $\cdot \alpha$-Aminoadipic semialdehyde $\cdot \alpha$-Aminoadipic acid $\cdot$ Oxidative stress $\cdot$ Maillard reaction $\cdot$ Protein oxidation $\cdot$ Nutrition $\cdot$ Safety $\cdot$ Disease

\begin{tabular}{|c|c|c|c|}
\hline \multicolumn{2}{|c|}{ Abbreviations } & GC & Gas chromatography \\
\hline \multirow{2}{*}{$\begin{array}{l}4-\mathrm{HNE} \\
\alpha-\mathrm{AA}\end{array}$} & 4-Hydroxynonenal & GIT & Gastrointestinal tract \\
\hline & $\alpha$-Aminoadipic acid & GO & Glyoxal \\
\hline$\alpha$-AS & $\alpha$-Aminoadipic semialdehyde & HAVA & Hydroxyaminovaleric acid \\
\hline$\gamma$-GS & $\gamma$-Glutamic semialdehyde & HACA & Hydroxyaminocaproic acid \\
\hline & Acetaldehyde & HPLC & High-performance liquid chromatography \\
\hline DNPH & Dinitrophenylhydrazine & HSA & Human serum albumin \\
\hline \multirow{3}{*}{\multicolumn{2}{|c|}{ Fluoresceinamine }} & $\mathrm{MCO}$ & Metal-catalysed oxidation \\
\hline & & MDA & Malondialdehyde \\
\hline & & MGO & Methyl glyoxal \\
\hline \multicolumn{2}{|c|}{ Handling editor: D. Tsikas. } & MR & Maillard reaction \\
\hline \multirow{2}{*}{\multicolumn{2}{|c|}{$\begin{array}{l}\triangle \text { Mario Estévez } \\
\text { mariovet@unex.es }\end{array}$}} & $\mathrm{MS}$ & Mass spectrometry \\
\hline & & ROS & Reactive oxygen species \\
\hline \multicolumn{2}{|c|}{1 Food Technology, IPROCAR Research Institute, Universidad } & WHC & Water-holding capacity \\
\hline
\end{tabular}




\section{Introduction}

Oxidative stress is a major cause of post-translational changes in proteins and includes severe chemical modifications such as aggregation via protein crosslinks and fragmentations via peptide scission (Davies 2016; Kehm et al. 2021). The oxidation of the aminoacids' side chain leads to the formation of derivatives of assorted nature including sulphur compounds (i.e. methionine sulphoxide; from methionine), aromatic species (i.e. kynurenines; from tryptophan) and carboxylic acids ( $\alpha$-aminoadipic acid; $\alpha$-AA; from lysine) (Estévez et al. 2020; Davies 2016). In food systems, these chemical changes are manifested in loss of protein functionality and digestibility with relevant consequences in terms of food protein quality and nutritional value (Soladoye et al. 2015; Xiong and Guo 2021). In cells and living organisms, protein oxidation is linked to biological impairments, aging and the onset of various pathological conditions (Akagawa 2020).

The formation of protein carbonyls typically responds to the oxidative deamination of alkaline amino acids such as lysine, arginine and proline (Estévez 2011; Davies 2016). The $\alpha$-aminoadipic semialdehyde ( $\alpha$-AS) is a specific oxidation product from lysine and account for up to the $70 \%$ of total protein carbonyls in cells (Requena et al. 2001) and food systems (Estévez 2011). Owing to their ubiquity in oxidized proteins and their simple detection and quantification by the routine dinitrophenylhydrazine (DNPH) method, protein carbonyls have been emphasized as general markers of protein oxidation in foods, cells and tissues (Estévez 2011; Hellwig 2020). Yet, limitations in both, accuracy of the technique, and the interpretation of the data, makes the DNPH method unsuitable to gain knowledge of scientific in-depth and mechanistic nature (Estévez et al. 2019; Hellwig 2020; Estévez 2021). The understanding of the intricate chemistry behind protein carbonylation is essential to comprehend its biological meaning. More accurate and advanced methodologies have been proposed to gain further insight into the molecular basis of the formation and biological effects of protein carbonyls (Fedorova et al. 2014; Hellwig 2020). Owing to the application of spectroscopic and mass spectrometric methodologies, recent relevant advances have been made in regards to the role of the Maillard reaction and the glyco-oxidation as alternative routes for protein carbonylation in biological samples (Trnková et al. 2015; Arcanjo et al. 2018; Luna et al. 2021). On the same line, recent studies have reported innovative evidence on the toxicological effects of dietary protein carbonyls and other oxidized amino acids (Estévez and Xiong 2019) and the role of these compounds in cell signalling mechanisms (Wong et al. 2012; Kehm et al. 2021). This review concisely collects and analyses the most recent advances in this topic and aims to elucidate future challenges.

\section{Concise update on carbonylation chemistry}

Carbonylation is an irreversible post-translational modification through which carbonyl moieties are formed and/ or introduced in proteins. This reaction takes place under various mechanisms of diverse nature though it is generally accepted that carbonylation typically takes place in a pro-oxidative environment and as a result of oxidative stress (Fedorova et al. 2014; Akagawa 2020). Notable exceptions should be denoted such as the carbonylation that occurs in certain cells and tissues under physiological conditions such as the formation of $\alpha$-AS from lysine prior to condensation reactions in connective tissue (Xu and Shi 2014). This reaction, is yet, enzymatically controlled (e.g. lysyl oxidase) and does not respond to the non-enzymatic oxidative stressinduced conditions in which uncontrolled protein carbonylation commonly occurs. Depending on whether carbonyls are formed in proteins or introduced in proteins subsequent to its formation, two types of protein carbonylation can be clearly discriminated. "Primary carbonyls" are formed on-site consequently to an oxidative damage to the protein structure while "secondary protein carbonyls" are formed from lipid oxidation and subsequently introduced in proteins via covalent linkages (Estévez et al. 2019; Akagawa 2020). In turn, the former can be generated via three mechanisms, namely, (i) oxidative deamination of alkaline amino acids (lysine, threonine, arginine and proline) by a radicalmediated mechanism; (ii) oxidative deamination of alkaline amino acids by dicarbonyls from the Maillard reaction (MR); and (iii) by oxidative cleavage of the peptide backbone via the $\alpha$-amidation pathway or via oxidation of glutamyl side chains (Berlett and Stadtman 1997; Estévez 2011; Akagawa 2020). Quantitatively, it is generally assumed that the latter among these three mechanisms is of negligible importance, and it is unusually reported as a source of protein carbonyls in biological samples. Among the relevant primary carbonylation mechanisms, the radical-mediated, known as 'Stadtman' pathway (Fig. 1A), normally involves a metal-catalysed oxidation (MCO) mechanism with the Fenton reaction being source of hydroxyl radicals and other reactive oxygen species (ROS) (Stadtman and Levine 2003). The reactive species would attack the $\varepsilon$-amino moiety from the alkaline amino acid by abstracting a hydrogen atom from the neighbouring carbon, leading to the formation, in a first step, of an imino group. This intermediate and unstable product is readily hydrolysed to form the corresponding protein carbonyl. According to this reaction pathway, the $\alpha$-AS, also known as allysine, is formed from the oxidative deamination of lysine while the $\gamma$-glutamic semialdehyde 
(A)

\section{Hydroxyl \\ Radical}

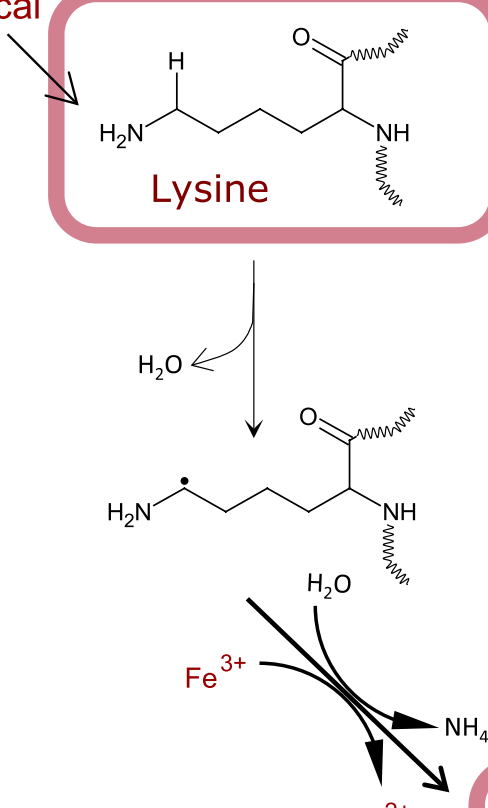

$\mathrm{Fe}^{2+}$

(B)
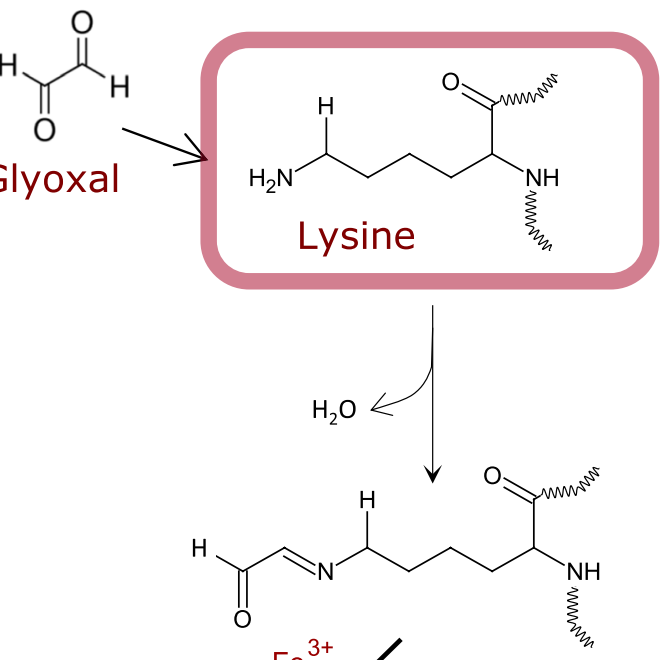

Fig. 1 Mechanisms of primary carbonylation: formation of $\alpha$-aminoadipic acid ( $\alpha$-AS). A Radical-mediated oxidative deamination of proteinbound lysine; B Maillard-mediated oxidative deamination of protein-bound lysine

$(\gamma$-GS) is formed from arginine and proline (Stadtman and Levine 2003; Estévez 2011). The alternative MR mediated mechanism, known as the 'Suyama' pathway (Fig. 1B), and also described as glyco-oxidation, implies the degradation of reducing sugars and the formation of reactive $\alpha$-dicarbonyls such as glyoxal (GO) and methylglyoxal (MGO) (Akagawa et al. 2005). These highly reactive dicarbonyls react with $\varepsilon$-amino groups in proteins causing the oxidative deamination of the alkaline amino acids and the formation of the same aforementioned protein carbonyls. Hence, both mechanisms lead to the same oxidation products and depending on the experimental approach and detection method, the relative contribution of each pathway to the carbonylation of proteins is indefinite. In food systems, most authors assume that protein oxidation, typically assessed as protein carbonylation, is the result of a radical-mediated mechanism (Estévez 2011; Hellwig 2020). Yet, recent results indicate that the glyco-oxidation of proteins leading to the formation of primary carbonyls is not only applicable. Under favourable conditions (e.g. occurrence of reducing sugars), this mechanism may be even most relevant than ROS-mediated carbonylation (Luna and Estévez 2019; Luna et al. 2021).
Villaverde and Estévez (2013) originally reported the occurrence of Maillard-mediated protein carbonylation in myofibrillar proteins at as low concentrations of glucose as those found in post-mortem muscle $(\sim 0.02 \mathrm{M})$. Luna and Estévez (2018) subsequently observed that glucose $(0.05 \mathrm{M})$ was more efficient than hydrogen peroxide $(0.6 \mathrm{mM})$ in reacting with metal ions to create the required pro-glyco-oxidative environment to induce protein carbonylation in a variety of food proteins, including meat proteins, ovalbumin, $\beta$-lactoglobulin and soy proteins. In a following study, the same authors confirmed the involvement of GO and MGO in the "Suyama pathway" and found that glyco-oxidized meat and dairy proteins displayed impaired functionality and digestibility (Luna and Estévez 2019). Recent studies performed in a variety of food proteins such as glutenin (Wang et al. 2019a) and $\alpha$-lactalbumin (Wu et al. 2021), have confirmed severe chemical changes induced by reactive Maillard dicarbonyls. While this mechanism may be highly relevant in food systems with high protein and sugar concentration (i.e. fermented meat products or certain dairy foods), the carbonylation of proteins in such foods is rarely attributed to this pathway by food scientists. The carbonylation of proteins 
during digestion has also been hypothesized to be affected by sugar concentration (Duque-Estrada et al. 2019). In a recent study, we observed that $10 \mathrm{mg} / \mathrm{mL}$ of glucose and GO strikingly promoted the carbonylation of meat proteins during simulated gastric digestion (unpublished data). The concentration of total protein carbonyls in the glyco-oxidized proteins increased $\sim 20$-fold times in meat proteins digested in the presence of glucose vs the control counterparts.

In living systems, the "Suyama pathway" was originally described to occur in plasma proteins from diabetic rats (Akagawa et al. 2006). The authors precisely described the underlying mechanisms and the role of GO and MGO in such carbonylation process (Akagawa et al. 2006). In the last five years, subsequent studies have contributed to identify the routes and mechanisms of protein carbonylation in proteins from plasma and other tissues under pathological hyperglycemic conditions. Given the connection between protein carbonylation in diabetic patients and the onset of oxidative stress and the metabolic syndrome (Hecker and Wagner 2018), strategies of carbonylation inhibition have been proposed to alleviate the associated biological impairments. Özyurt et al. (2016) reported fourfold increases of specific semialdehydes in human hemoglobin and human serum albumin (HSA) upon exposure to simulated hyperglycemic conditions ( $12 \mathrm{mM}$ glucose $/ 0.2 \mathrm{mM} \mathrm{Fe}^{3+}$ ) for 10 days. Epicatechin, epigallocatechin and epigallocatechin-3-gallate at $0.7 \mu \mathrm{M}$, were found to keep protein carbonyls at basal levels through anti-glycation mechanisms. Arcanjo et al. (2018) was able to double the concentration of $\alpha$-AS and $\gamma$-GS in HSA upon incubation with pathological concentrations of GO and MGO (0.4 mM; Lapolla et al. 2003) for $48 \mathrm{~h}$. The same authors found that resveratrol $(2.5 \mu \mathrm{M})$ effectively inhibited the carbonylation of HSA by forming adducts with the aforementioned Maillard dicarbonyls. More recently, Luna et al. (2021) reported that glucose induces dose-dependent carbonylation of HSA at relevant pathophysiological concentrations $(4-12 \mathrm{mM})$ and observed that the main protein carbonyl ( $\alpha$-AS) suffered a further oxidation step to yield the lysine oxidation end product, the $\alpha$-amino adipic acid ( $\alpha$-AA). Interestingly, this oxidized form of lysine has been recently emphasized as an early and reliable marker of insulin resistance and diabetes in humans (Lee et al. 2019).

Finally, considerable progresses have also been made in relation to the understanding of the chemistry involved in the formation of secondary protein carbonyls. Malondialdehyde (MDA), 4-hydroxynonenal (4-HNE) and other lipid-derived carbonyls have been found to react with protein-bound amino groups and form complexes with food proteins (Zhou et al. 2015; Gürbüz and Heinonen 2015; Wang et al. 2019b). Unlike the aforementioned dicarbonyls from MR (GO and MGO), MDA and other lipid carbonyls are unable to induce the oxidative deamination of lysine residues to yield primary protein carbonyls such as $\alpha$-AS from lysine. Instead, MDA and 4-HNE remain bound to proteins as secondary protein carbonyls via a Michael addition-type reaction (Fig. 2). This reaction occurs between MDA [and its degradation products, acetaldehyde (AA) and formaldehyde (FA) and other carbonyls], and lysine and other alkaline amino acids to form adducts of assorted stability. It is worth noting that a second aldehyde moiety from the added MDA remains free and available to react with DNPH or other derivatization agents, which enables its detection as (secondary) protein carbonyls. Alternatively, the free aldehyde from a protein-bound MDA could react with another lysine residue, which leads to the formation of intra- and/or intermolecular covalent crosslinks. In a recent study, Estévez et al. (2019) observed that the accretion of protein hydrazones (DNPH-derivatized

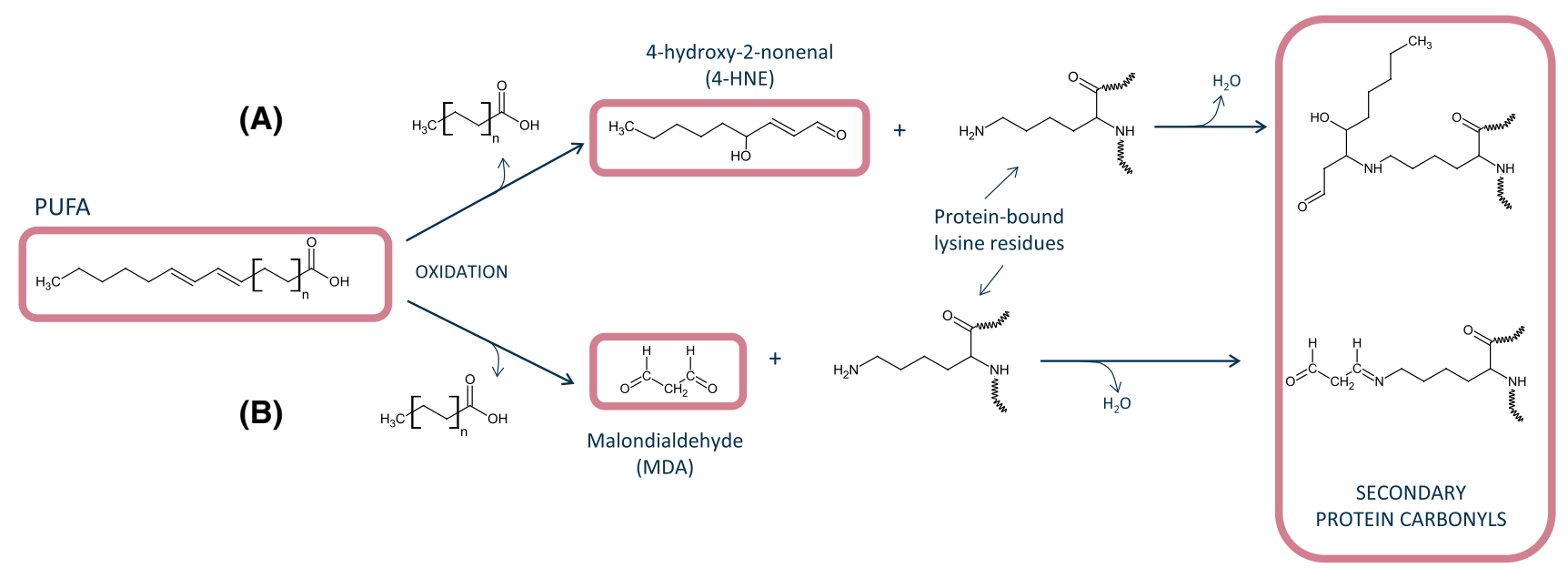

Fig. 2 Mechanisms of secondary carbonylation. A Michael addition of 4-hydroxynonenal to protein-bound lysine; B Michael addition of malondialdehyde to protein-bound lysine 
carbonyls) in HSA was affected by the exposure to a broad concentration range of MDA $(0.05-5 \mathrm{mM})$. The authors concluded that the concentration of secondary protein carbonyls, corresponding to protein-bound MDA, increased with the concentration of MDA. The extent of carbonylation in HSA exposed to $5 \mathrm{mM}$ peaked at around $22 \mathrm{nmol}$ per mg of protein. At such experimental concentrations, the addition of MDA molecules to lysine residues occurs at so high levels, that the formation of primary protein carbonyls from such alkaline amino acid is completely inhibited. The authors report that in foods or biological systems subjected from moderate to severe lipid oxidation (concentrations of MDA between 0.05 and $1 \mathrm{mM}$ ), between 50 and $80 \%$ of protein carbonyls detected by the DNPH method would be secondary carbonyls. According to the recent and interesting results reported by Wang et al. (2019b), MDA may not only be responsible of secondary carbonylation of myoglobin and myofibrillar proteins from rabbit skeletal muscle. This lipid-derived carbonyl may be able to induce the formation of hypervalent myoglobin species, which promotes the creation of a pro-oxidative environment in the muscle tissue, and worsen, in turn, the oxidative stress. The comprehensive review by Tsikas (2017) provides further details on the formation, reactivity and analytical methods of MDA. Other reactive carbonyls such as acrolein and crotonaldehyde have been found to induce carbonylation stress in cells and other biological systems (Mello et al. 2007). Their implication in the secondary carbonylation of food proteins requires further elucidation.

\section{Concise update on methodological approaches}

The DNPH method is the most common procedure for the routine quantification of total protein carbonyls from a biological sample and the results are broadly used as a general index of protein oxidation (Estévez 2011; Hellwig 2020). The technique involves a concurrent spectrophotometric determination of DNPH-derivatized protein-bound carbonyls [as 2,4-dinitrophenyl (DNP) hydrazones] and the total protein content of the sample (Oliver et al. 1987). Eventually, the results are expressed as nmol protein hydrazones per $\mathrm{mg}$ of protein. It is worth emphasizing that (i) the original procedure was set to evaluate protein oxidation in plasma samples (Oliver et al. 1987) and that (ii) the DNPH reacts with carbonyl moieties regardless of the origin or formation pathway. Because of this, the method has been modified to facilitate the analysis of proteins from solid samples and low solubility (i.e. myofibrillar proteins) and to avoid interferences caused by lipid carbonyls and assorted chromophores. These modifications include the homogenization of solid samples with high ionic strength buffers and treating the samples with acid and organic solvents to eliminate interfering chromophores such as haemoglobin, retinoids or unreacted DNPH [reviewed by Estevez et al. (2008) and Hellwig (2020)]. Besides the in-solution procedure, in-gel techniques based on western blotting and ELISA-type immunodetection by DNPH-tagged protein antibodies, can also be applied (Meyer et al. 2012; Augustyniak et al. 2015). Despite of recent optimization of the DNPH method for the assessment of protein carbonylation in food systems (Soglia et al. 2016) and other biological samples (Colombo et al. 2016; Bayarsaikhan et al. 2019), this procedure suffers from lack of specificity and has been recurrently criticized for providing an unreliable estimation of the real extent of the protein oxidative damage.

In regards to the specificity, it is generally recognized that the DNPH method provides limited information on the nature and or formation pathway of the quantified carbonyls (Hellwig 2020). Further to that, the overestimation of protein carbonyls by accounting lipid carbonyls introduced into proteins has been recently reported as a major flaw of the DNPH method (Estévez et al. 2019). The authors found that MDA readily reacts with $\varepsilon$-amino groups from proteinbound lysine residues and as a result, the DNP hydrazones quantified correspond to a major extent (up to $80 \%$ of total protein carbonyls) to protein-bound MDA carbonyl moieties. Therefore, at a certain range of MDA concentrations (0.05-1 mM), both the formation of primary protein carbonyls by either MCO or MR pathways, and their subsequent detection, is partially blocked by MDA and likely, other lipid-derived carbonyls. It is hence, worth taking into consideration that under severe lipid oxidative environment and MDA production, protein carbonyls quantified by DNPH may mostly reflect a secondary carbonylation process (Fig. 3).

To gain specificity and information of mechanistic nature, the analysis of specific protein carbonyls by chromatographic techniques, such as $\alpha$-AS and $\gamma$-GS, is the election technique. These carbonyl compounds can be tagged by several derivatization procedures, eventually separated, and detected by HPLC or GC attached to fluorescence or MS detectors (Utrera et al. 2011; Estévez 2011; Hellwig 2020). p-Amino benzoic acid (p-ABA) has been used to tag and stabilize protein carbonyls prior to the hydrolysis procedure. The subsequent detection and quantification of p-ABA-derivatized carbonyls has been performed using MS (Estévez et al. 2009) and fluorescence detectors (Akagawa et al. 2009; Utrera et al. 2011). Alternative means of detection involves derivatization with fluoresceinamine $\left(\mathrm{FINH}_{2}\right)$ prior to separation and identification using HPLC-MS (Climent et al. 1989). The analysis of protein carbonyls by GC involves the prior preparation of volatile hydroxyl derivatives from $\alpha$-AS (hydroxyaminovaleric acid; HAVA) and $\gamma$-GS (hydroxyaminocaproic acid; HACA) and subsequent 


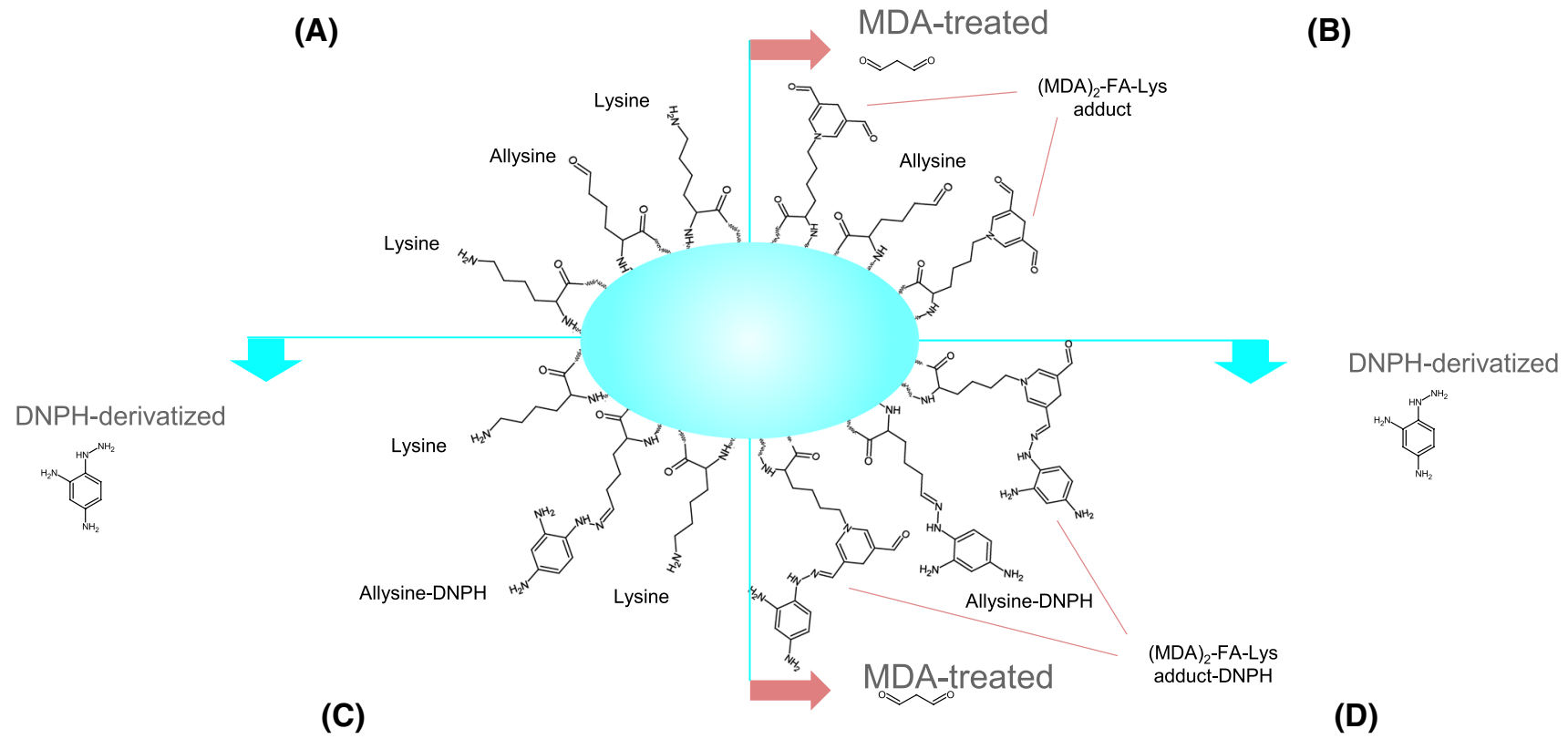

Fig. 3 Illustration of the overestimation of primary carbonylation in malondialdehyde-exposed proteins by the dinitrophenylhydrazine method as reported by Estévez et al. (2019). A-quadrant occurrence of protein-bound lysine and $\alpha$-AS residues, $B$-quadrant addition of malondialdehyde to protein-bound lysine residues, $C$-quandrant derivatization of protein-bound $\alpha$-AS residues by the dinitrophenylhydrazine, D-quadrant derivatization of protein-bound $\alpha$-AS and malondialdehyde residues by the dinitrophenylhydrazine reduction with sodium borohydride $\left(\mathrm{NaBH}_{4}\right)$ (Requena et al. 2001). Table 1 shows the concentration of protein carbonyls in various food products as analysed by the DNPH method or chromatographic techniques. Other innovative approaches include hydrazine-based derivatization prior to a 2D-electrophoresis gel analysis of redox proteomics (Malheiros 2019) and the cellular localization of protein carbonyls using mass spectrometry imaging (Flinders et al. 2015). The description of these and other methods for assessing protein oxidation in meat samples have been reviewed by Fedorova et al. (2014), Alomari et al. (2018), Hawkins and Davies (2019) and Hellwig (2020). Recent redox-proteomic approaches have contributed to understanding the occurrence of protein carbonylation and its underlying mechanisms in postmortem muscle from mammals (Sayd et al. 2012), seafood (Lin et al. 2021), processed meat (Malheiros 2019; Mitra et al. 2018) and various biological samples (Verrastro et al. 2015; Driessen et al. 2015).

\section{Concise update on the biological consequences of protein carbonylation}

Beyond their role as indicators of the extent of the oxidative damage to proteins, protein carbonyls may be directly implicated in the onset of processes leading to food quality deterioration, nutritional impairments, and pathophysiological conditions. The oxidation of lysine residues may have consequences on protein functionality and on the susceptibility of proteins to hydrolytic degradation. Further, protein carbonyls formed from lysine oxidation are reactive compounds, which are involved in the formation of crosslinks and carboxylic acids, with all of these having consequences of biological relevance. In this section, recent advances in the understanding of the impact of protein carbonylation on food quality, nutrition and health are concisely reported.

\section{Protein carbonylation and food protein functionality and digestibility}

Proteins are major components of foods from animal origin, and, therefore, play an indisputable role in the technological, nutritional, and sensory properties of muscle, dairy and egg foods. Soon after the discovery that muscle proteins were susceptible to oxidation and protein carbonyls were quantified in food samples, this oxidative damage was linked to loss of protein functionality including impairments of the ability to form gels, emulsions and hold water (Xiong 2000). In subsequent studies, carbonylation was also associated to decreased susceptibility of oxidized proteins to proteases, which had consequences on meat tenderization during aging (Rowe et al. 2004) and on protein degradation during digestion of severely oxidized foods (Sante-Lhoutellier et al. 2007; Soladoye et al. 2015). In a previous comprehensive review about protein carbonylation in meat systems, Estévez (2011) already warned that most causative connections 
Table 1 Concentration of protein carbonyls in various food products reported in recent literature

\begin{tabular}{|c|c|c|c|}
\hline Food system & Method & $\begin{array}{l}\text { Protein } \\
\text { carbonyls }\end{array}$ & References \\
\hline Raw lamb cutlets & DNPH & 9 & Lahmar et al. (2018) \\
\hline Ready-to-eat chicken patties & DNPH & 15 & de Santana Neto et al. (2021) \\
\hline Soy protein isolate & DNPH & 13.6 & Yu et al. (2018) \\
\hline Soy protein isolate & DNPH & 10.4 & Zhang et al. (2017) \\
\hline Milk & DNPH & $23.6^{\mathrm{B}}$ & Kalaitsidis et al. (2021) \\
\hline Yogurt & DNPH & $11.8^{\mathrm{B}}$ & Kalaitsidis et al. (2021) \\
\hline Feta cheese & DNPH & $30.9^{\mathrm{B}}$ & Kalaitsidis et al. (2021) \\
\hline Cooked ham & DNPH & 8 & Armenteros et al. (2016) \\
\hline Rainbow trout mince & DNPH & 3.6 & Bitalebi et al. (2019) \\
\hline Surimi fishballs & DNPH & 4.2 & Zhao et al. (2019) \\
\hline Powdered infant milk & DNPH & 3.1 & Chen et al. (2019) \\
\hline Silver carp fillets & DNPH & 4 & Zhang et al. (2021) \\
\hline Raw shrimp & DNPH & 11.9 & Ruvalcaba-Márquez et al. (2021) \\
\hline Blood meal & DNPH & 127 & Frame et al. (2020) \\
\hline Raw rabbit meat & DNPH & 7 & Wang et al. (2018) \\
\hline Air-dried yak meat & DNPH & 8.5 & Ma et al. (2021) \\
\hline Fresh pork & DNPH & 4.5 & Hernández-López et al. (2016) \\
\hline Cooked beef patties & HPLC $^{\mathrm{C}}$ & 1.3 & Rysman et al. (2016) \\
\hline Frozen rainbow trout fillet & HPLC $^{\mathrm{C}}$ & 4.5 & Timm-Heinrich et al. (2013) \\
\hline Fermented sausages & HPLC $^{\mathrm{C}}$ & 0.9 & Öztürk-Kerimoğlu et al. (2019) \\
\hline Fermented sausages & HPLC $^{\mathrm{C}}$ & 0.9 & Villaverde et al. (2014) \\
\hline Jerky chicken & HPLC $^{\mathrm{C}}$ & 85 & Silva et al. (2016) \\
\hline Cooked bacon & HPLC $^{\mathrm{C}}$ & 80 & Soladoye et al. (2017) \\
\hline Sous vide-cooked lamb loin & HPLC $^{\mathrm{C}}$ & 0.42 & Roldán et al. (2014) \\
\hline Raw wooden chicken breast & HPLC $^{\mathrm{C}}$ & 3.2 & de Carvalho et al. (2021) \\
\hline
\end{tabular}

$D N P H$ quantification of protein carbonyls as hydrazones according to the dinitrophenylhydrazine method, $H P L C$ quantification of specific protein carbonyls, $\alpha$-AS and $\gamma$-GS, by high-performance liquid chromatography

${ }^{A}$ Results expressed as nmol of protein carbonyls/mg protein, unless otherwise noted

${ }^{\mathrm{B}}$ Results expressed as ng of protein carbonyls/mL sample

${ }^{\mathrm{C}}$ Results refer to the sum of $\alpha$-AS and $\gamma$-GS between protein carbonyls and the alleged effects on protein functionality were based on the calculations of positive and significant correlations. Since correlation does not involve causation, only by defining the underlying molecular mechanisms of the deleterious effects of protein carbonylation on protein functionality and food quality, the causative connection between both events can be rationally supported. In this regard, great efforts have been made in the last years to comprehend such connections. Utrera and Estévez (2012) thoroughly reported the occurrence of the "carbonylation pathway" in myofibrillar proteins subjected to a radical generating system. The formation of $\alpha$-AS, as an early product from lysine oxidation, was followed by the formation of its oxidative degradation product $(\alpha-\mathrm{AA})$ and the formation of Schiff bases upon reaction of $\alpha$-AS with protein-bound amino groups. These chemical changes were proposed to contribute to the impaired water functionality of meat proteins. Namely, the authors indicated that protein carbonylation could likely alter protein-water molecular interactions by (i) modification of the isoelectric point in oxidized proteins and (ii) by formation of protein aggregates; with both processes explaining an impaired protein functionality. Conversely, Bao et al. (2018) observed that protein carbonylation and protein crosslinks affected protein net charges though protein functionality was eventually improved. Yet, the authors induced oxidation by hypochlorous acid, and the results seemed to diverge from those reported by Utrera and Estévez (2012) who employed a hydroxyl radical oxidation system. Using a similar in vitro radical-induced oxidation system, Zhang et al. (2020) recently confirmed that protein crosslinking, aggregation and other severe structural changes in oxidized proteins compromise their water solubility and functionality. As recently reviewed by Zhao et al. (2021), the functionality of muscle proteins, including their ability to hold water and form gels, can be modulated by an appropriate management of the nature and extent of protein 
oxidation. Xiong (2000) already reported that mild and progressive protein oxidation may facilitate protein functionality and leads to stable gels, while severe oxidation leads to decreased protein functionality and impaired rheological properties. Numerous scientific evidences support this hypothesis and interestingly, phytochemicals (polyphenols, phenolic acids) may contribute to modify the functional and rheological properties of gels from mild to moderately oxidized proteins (Guo and Xiong 2021). The carbonylation of proteins via the "Suyama" pathway (Maillard-mediated mechanism) has also been found to affect the functionality of meat, dairy and soy proteins (Luna and Estévez 2019; Feng et al. 2021). Luna and Estévez (2019) observed that incubation of $\beta$-lactoglobulin and myofibrillar proteins with GO and MGO $(2 \mathrm{M})$ at $80{ }^{\circ} \mathrm{C}$ cause severe carbonylation ( $>20$ $\mathrm{nmo} / \mathrm{mg}$ protein) and reduced ability of the carbonylated proteins to hold water ( $90 \%$ loss of functionality). Glucosetreated soy proteins have also been reported to undergo extremely severe carbonylation and impaired surface properties when heated at $60{ }^{\circ} \mathrm{C}$ for $24 \mathrm{~h}$ (Feng et al. 2021). The occurrence of secondary carbonylation has also been found to affect protein functionality though the effect depends on the nature of the lipid-derived carbonyl and its concentration. Cheng et al. (2021a, b) recently observed that 5-20 mM MDA improved the WHC and rheological properties of gels from myofibrillar proteins while at even higher MDA concentrations $(40 \mathrm{mM})$, the emulsion gel was completely lost. It is worth clarifying that these experimental MDA concentrations are out of the range found in processed or digested food products (Steppeler et al. 2016). Table 2 shows recent data on the concentration of protein carbonyls, MDA and 4-HNE in food digests. Wang et al. (2021) reported deleterious effects of $5 \mathrm{mM}$ MDA on the functionality of myofibrillar proteins while these effects were found to be counteracted by phenolic terpenes such as linalool or limonene. The MDA-induced oxidative stress and consequent impaired functionality in myofibrillar proteins can also be modulated by the ionic strength of the media, which is dependent, in turn, on $\mathrm{NaCl}$ concentration (Zhou et al. 2015). In a recent paper, Keller et al. (2020) reported the heme-iron-induced production of 4-HNE in the intestinal lumen and the role of this reactive carbonyl in the formation of protein-adducts in heart, liver and skeletal muscle of rats.

The impact of protein carbonylation on protein digestibility has also been a topic of recurring debate. As for the impact on the functional properties, the effect of the carbonylation of the susceptibility of proteins to undergo hydrolytic degradation depends on the severity of the oxidative damage. In this regard, mild protein oxidation may favour partial unfolding which facilitates enzymatic approach, recognition and action on the substrate. Conversely, the formation of irreversible protein aggregates owing to a severe and enduring oxidative damage may lead to a decreased proteolytic susceptibility (Soladoye et al. 2015). Morzel et al. (2006) ascribed the decreased susceptibility of oxidized myofibrillar proteins to papain, to the carbonylation of arginine and lysine as this enzyme hydrolyses at bonds involving such amino acids. In this regard, similar effects could be expected
Table 2 Concentration of protein carbonyls (PC), malondialdehyde (MDA) and 4-hydroxynonenal (4-HNE) in various food digests

\begin{tabular}{llllll}
\hline Food system & GID $^{\mathrm{A}}$ & $\mathrm{PC}^{\mathrm{B}}$ & MDA & 4-HNE & References \\
\hline Processed pork & Simulated static system (i) & 8 & $30^{\mathrm{C}}$ & - & Van Hecke et al. (2018) \\
Mackerel & Simulated static system (i) & 13 & $0.88^{\mathrm{D}}$ & $34^{\mathrm{E}}$ & Van Hecke et al. (2019) \\
Salmon & Simulated static system (i) & 9.5 & $0.53^{\mathrm{D}}$ & $19^{\mathrm{E}}$ & Van Hecke et al. (2019) \\
Tuna & Simulated static system (i) & 5.5 & $0.55^{\mathrm{D}}$ & $13^{\mathrm{E}}$ & Van Hecke et al. (2019) \\
Parma ham & Simulated static system (g) & 9 & $65^{\mathrm{F}}$ & $8^{\mathrm{F}}$ & Goethals et al (2020) \\
Cooked chicken patties & Simulated static system (i) & 10 & $124^{\mathrm{F}}$ & $200^{\mathrm{F}}$ & Sobral et al. (2020) \\
Dry-cured loin & Simulated static system (i) & 23 & $0.8^{\mathrm{G}}$ & - & Lavado et al. (2021) \\
Red cured cooked meat & Simulated static system (g) & 8 & $0.4^{\mathrm{D}}$ & $140^{\mathrm{E}}$ & Van Hecke et al. (2021) \\
& Sprague-Dawley rats (g) & 7 & $100^{\mathrm{F}}$ & - & Van Hecke et al. (2021) \\
Cooked pork & Simulated static system (g) & 5 & $5^{\mathrm{H}}$ & $240^{\mathrm{I}}$ & Li et al. (2021a, b) \\
\hline
\end{tabular}

${ }^{\mathrm{A}} G I D$ Gastrointestinal digestion system. (i) data collected at the intestinal digestion phase. (g) data collected at the gastric digestion phase

${ }^{\mathrm{B}}$ Results expressed as nmol of protein carbonyls/mg protein

${ }^{\mathrm{C}}$ Results expressed as $\mathrm{nmol} / \mathrm{mL}$ digest

${ }^{\mathrm{D}}$ Results expressed as $\mathrm{mmol} / \mathrm{kg}$ digest

${ }^{\mathrm{E}}$ Results expressed as $\mu \mathrm{mol} / \mathrm{kg}$ digest

${ }^{\mathrm{F}}$ Results expressed as $\mathrm{nmol} / \mathrm{g}$ digest

${ }^{\mathrm{G}}$ Results expressed as $\mu \mathrm{mol} / \mathrm{mL}$ digest

${ }^{\mathrm{H}}$ Results expressed as $\mu \mathrm{g} / \mathrm{mL}$ digest

${ }^{\mathrm{I}}$ Results expressed as $\mathrm{ng} / \mathrm{mL}$ digest 
for digestive enzymes with a similar hydrolytic pattern like trypsin. Protein carbonyls could also impair the digestibility of food proteins by contributing to the formation of insoluble aggregates via carbonyl-amine crosslinks. SanteLhoutellier et al. (2007) found that the activity of trypsin/ $\alpha$ chymotrypsin on proteins decreased as the carbonylation level in the latter increased, which provides strength to the role of protein carbonylation on the impaired digestibility of oxidized proteins. According to recent literature, the carbonylation of proteins via the Maillard reaction (Luna and Estévez 2019; Wu et al. 2021) or via introduction of secondary lipid carbonyls such as MDA (Niu et al. 2019; $\mathrm{Li}$ et al. 2021a, b) have a deleterious impact on the digestibility of meat, dairy and cereal proteins. Recent studies have also established plausible connections between the extent of protein carbonylation and a reduced digestibility of proteins in a variety of foods such as egg white (Cheng et al. 2021a, b), whey isolate (Niu et al. 2019), ready-to-eat chicken patties (Ferreira et al. 2018), fish fillets (Semedo Tavares et al. 2018) and air-dried yak meat (Ma et al. 2021), among many others.

\section{Protein carbonylation and toxicological concerns}

The intake of oxidized lipids is known to increase the post-prandial plasma levels of oxidation and inflammation markers (Sies et al. 2005; Estévez et al. 2017). A sustained exposure to dietary lipid oxidation products is associated with an increased risk of suffering certain chronic inflammatory diseases and cancer (Sies et al. 2005). The molecular basis of this pathogenesis is well documented, as lipid-derived carbonyls such as MDA are known to display cytotoxic and mutagenic potential in the gastrointestinal tract (GIT) or in internal organs upon absorption (Esterbauer 1993). In this scenario, it is reasonable to enquiry whether dietary protein carbonyls may also contribute to impair cell homeostasis and induce health disorders. There is, in this regard, a profound lack of knowledge. The high reactivity of $\alpha$-AS and other protein carbonyls, and the poor commercial availability of purified compounds, hinders the implementation of toxicological studies using such species. Alternatively, experimental animals have been fed with severely oxidized proteins in which carbonyls appeared to be one of the most salient chemical modifications. Using this experimental approach, Li et al. (2014) found that dietary oxidized proteins promoted the collapse of endogenous antioxidant cell defense systems, leading to the onset of oxidative stress and degeneration in kidney and liver of mice. The intake of severely carbonylated beef proteins to Wistar rats has been reported to have a significant impact on gut microbiota (Van-Hecke et al. 2021). To similar conclusions came Ge et al. (2020) who found that the alteration of the gut microbiota in mice by the intake of oxidized pork contributed to the onset of oxidative stress and inflammation processes in this murine model. The same authors reported that dietary oxidized pork induced impaired lipid metabolism by decreasing insulin levels and suppressing of the insulin receptor substrate-1 (IRS-1)/ phosphoinositide 3-kinase (PI3K)/protein kinase B (Akt) signaling pathway and its downstream signaling molecules (Ge et al. 2021). Li et al. (2019) observed impaired spatial learning and memory in rats fed with carbonylated proteins from a severely processed milk product. While these studies support the role of dietary protein oxidation on physiological disorders, the identification of specific protein oxidation products as responsible for such effects is unfeasible. To comprehend the impact of particular oxidized amino acids, we recently carried out an experiment (unpublished data) in which Wistar rats were exposed to $\alpha$-AS/piperideine-6-carboxylate in acute $(5 \mathrm{mg} /$ day $/ \mathrm{kg}$ live weight for 4 weeks $)$ and chronic assays $(0.5 \mathrm{mg} / \mathrm{day} / \mathrm{kg}$ live weight for 20 weeks). Among the most remarkable results, we observed the onset of oxidative stress in several tissues (e.g. small intestine, liver, spleen) and impaired lipid metabolism in treated rats vs. the control counterparts, which agrees with results obtained from some of the aforementioned studies. The most abundant protein carbonyl, $\alpha$-AS, is oxidized in the presence of peroxides to the lysine oxidation end product, the $\alpha$-AA. This transformation is readily taking place in pro-oxidative environments such as that created in hyperglycemic conditions (Luna et al. 2021). Unlike its precursor, this oxidized amino acid has been profusely studied in regards to its ability to induce pathological conditions. In a recent study, Díaz-Velasco et al. (2020) documented that the exposure of human CACO-2 cells to a food-relevant $\alpha$-AA concentration $(200 \mu \mathrm{M})$ leads to depletion of glutathione, oxidative stress, apoptosis and necrosis (Fig. 4). In a further study using proteomics (unpublished data), the $\alpha$-AA was found to act as analog of glutamic acid and impair multiple biological processes in human intestinal cells such as the transepithelial transport, mitochondrial activity and protein repair mechanisms. Wang et al. (2013) induced pancreatic malfunction and diabetes in C57BL/6 mice by oral administration of $\alpha$-AA $(500 \mathrm{mg} /$ day/kg live weight). Estaras et al. (2020) challenged mice pancreatic acinar cells with $200 \mu \mathrm{M} \alpha$-AA and observed oxidative stress, calcium homeostasis dysfunction and impaired trypsin secretion. More details on the effect of dietary protein oxidation on human health can be found elsewhere (Estévez and Luna 2017; Estévez and Xiong 2019). Likewise, the application of antioxidant strategies to mitigate the negative consequences of the onset of lipid and protein oxidation in foods and in the gastrointestinal tract have been recently reviewed critically and comprehensively 
Fig. 4 Mechanisms of the cytotoxic effects of $\alpha$-AA on CACO-2 cells as reported by Díaz-Velasco et al. (2020)

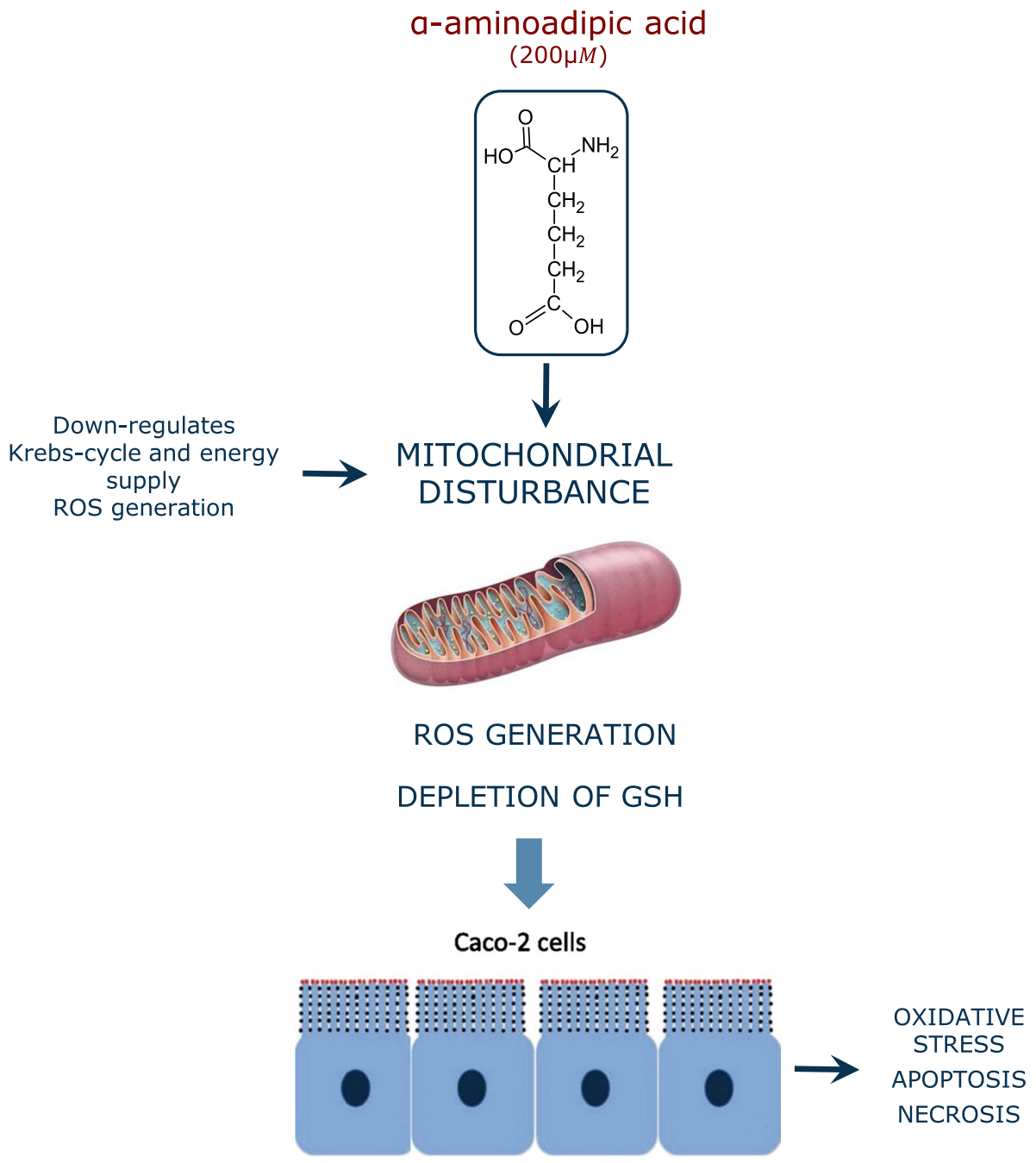

(Nieva-Echevarría et al. 2020; Lund 2021; Estévez 2021; Xiong and Guo 2021).

\section{Protein carbonylation as mechanism of cell communication}

For a long time regarded as markers of protein oxidation, protein carbonyls have been found to participate actively in biological processes and metabolic functions. The understanding of the molecular basis of such bioactivities may be required to identify the role of protein carbonyls in the onset of physiological impairments and pathological conditions. Considering that protein carbonyls are still highly reactive and can be involved in carbonylamine reactions, with this reaction being key in many enzymatic and biological processes, it is plausible to hypothesize that protein carbonyls may act as signalling molecules. The role of protein carbonylation as a reaction of biological consequences is relevant from a food and nutrition perspective, considering the accretion of carbonyls in dietary proteins during processing, storage, culinary preparation and digestion. While the toxicological aspects of $\alpha$-AS, as major protein carbonyl, and its oxidation product ( $\alpha-\mathrm{AA})$, are still being examined, the dietary exposure to physiological concentrations of these oxidized amino acids may also play a role in the regulation of certain internal physiological processes upon absorption. Unfortunately, these effects are poorly understood. Likewise, the in vivo carbonylation of proteins in cells may also be implicated in mechanisms of cell regulation and control. In the following lines, the most recent discoveries of protein carbonyls as redox signaling molecules are concisely reviewed.

One of the main biological consequences of protein carbonylation is the activation of the protein turnover mechanism. As protein carbonylation is irreversible and cellular enzymes are unable to repair such oxidative damage, carbonylated proteins are degraded by the cell's proteasomal system (Baraibar and Friguet 2012). Otherwise, severely carbonylated proteins may not only be dysfunctional, they tend to form aggregates via increasing intrinsic protein 
hydrophobicity and the formation of carbonylamine reactions (Schiff-base structures) between protein carbonyls and $\varepsilon$-amino groups from protein-bound alkaline amino acids (i.e. lysine). The accumulation of aggregates of oxidized proteins in cells and tissues has been highlighted as a pathological hallmark of serious health disorders such as the Alzheimer disease (Levine 2002; Sharma et al. 2020). While cells may degrade aberrant proteins by whether the ATP-ubiquitin dependent $26 \mathrm{~S}$ proteasome or by the ATPubiquitin independent $20 \mathrm{~S}$ proteasome, carbonylated proteins seem to be preferentially degraded by the $20 \mathrm{~S}$ proteasome (Jung and Grune 2008; Baraibar and Friguet 2012; Lefaki et al. 2017). It is worth noting that certain proteins may be more susceptible to carbonylation than others but the molecular basis of this specificity still remained unclear though it may respond to mechanisms of protein tagging in turn over or other cellular signaling mechanisms (Maisonneuve et al. 2009). Additionally, severely carbonylated and aggregated proteins are not recognized by the $20 \mathrm{~S}$ proteasome, which leads to accretion of such oxidized complexes in cell.

Other works indicate the role of protein carbonylation on mitochondrial function and insulin resistance in muscle and adipose tissue (Frohnert and Bernlohr 2013). According to these authors, carbonylation of proteins may display opposite effects depending on the role of the proteins being affected by this post-translational modification. In this regard, certain proteins such as Kelch-like ECH-associated protein 1 (KEAP1) are activated in antioxidant response through carbonylation while insulin receptor substrates 1 and 2 are inactivated when carbonylated, which decreases insulin signaling. Another example is the activation of $c$-Jun $\mathrm{N}$-terminal kinase (JNK) upstream kinase ASK1 by secondary carbonylation via 4-HNE adduction. The activation of this pathway leads to the ultimate expression of pro-inflammatory target genes, linking oxidative stress and inflammation (Curtis et al. 2012; Hecker and Wagner 2018). Proposing a pioneering theory, Wong et al. (2013) reported that primary protein carbonylation could be a physiological mechanism of ROS signaling and that such mechanism is regulated by decarbonylation. Therefore, according to their proposal, the formation of protein carbonyls could be reversed by the involvement of cell reductases, which clearly diverge from the wellestablished assumption that carbonylation was an irreversible damage to proteins. As a supportive example of their theory, the authors observed that carbonylation of annexin A1, which shows anti-inflammatory, anti-proliferative and pro-apoptotic effects, leads to its degradation by the proteasome. This oxidation-driven degradation of annexin A1 is proposed as a cell signal for cell growth. Though the authors suggest that certain enzymes and redox proteins, such as alcohol dehydrogenases and thioredoxin, may be involved in decarbonylation of proteins, it is currently unclear whether free or protein-bound oxidized amino acids such as $\alpha$-AS or $\gamma$-GS could be reduced under physiological conditions.

\section{Concluding remarks}

The recent advances achieved in the field of protein carbonylation facilitate the understanding of the biological significance of this multifaceted reaction. While the carbonylation on food proteins is typically regarded as a reaction of negative consequences owing to the loss of nutritional value, decreased digestibility and impaired functionality, scientific evidences support the benefits of mild and controlled oxidation of proteins in the improvement of their gel abilities and rheological properties. Likewise, the onset of protein carbonylation in cells may play a double role, depending on the severity of the reaction and the protein target of such post-translational modification. On the one hand, severe and enduring oxidative stress leading to massive protein carbonylation and aggregation may block protein turnover and cause pathological conditions related to oxidative stress and inflammation. On the other hand, mild and/or targeted carbonylation in particular proteins may induce physiological responses for the strengthening of the antioxidant defences, the activation of the protein turnover and likely modulation of the immune system. As a truly open topic, further and inspiring discoveries will contribute to consolidate the connections between protein carbonylation, food quality, nutrition and health.

Funding Open Access funding provided thanks to the CRUE-CSIC agreement with Springer Nature. The support from the "FEDER/Ministerio de Ciencia, Innovación y Universidades-Agencia Estatal de Investigación" through the Project: AGL2017-84586-R is acknowledged. Likewise, finantial support was also received from "Gobierno de Extremadura (Consejería de Economía e Infraestructuras)" through the Grant GR18104.

\section{Declarations}

Conflict of interest The authors have no conflicts of interest to declare that are relevant to the content of this article.

Open Access This article is licensed under a Creative Commons Attribution 4.0 International License, which permits use, sharing, adaptation, distribution and reproduction in any medium or format, as long as you give appropriate credit to the original author(s) and the source, provide a link to the Creative Commons licence, and indicate if changes were made. The images or other third party material in this article are included in the article's Creative Commons licence, unless indicated otherwise in a credit line to the material. If material is not included in the article's Creative Commons licence and your intended use is not permitted by statutory regulation or exceeds the permitted use, you will need to obtain permission directly from the copyright holder. To view a copy of this licence, visit http://creativecommons.org/licenses/by/4.0/. 


\section{References}

Akagawa M (2020) Protein carbonylation: molecular mechanisms, biological implications, and analytical approaches. Free Radic Res. https://doi.org/10.1080/10715762.2020.1851027

Akagawa M, Sasaki D, Kurota Y, Suyama K (2005) Formation of $\alpha$-aminoadipic and $\gamma$-glutamic semialdehydes in proteins by the Maillard reaction. Ann NY Acad Sci 1043:129-134. https://doi. org/10.1196/annals.1333.016

Akagawa M, Sasaki D, Ishii Y et al (2006) New method for the quantitative determination of major protein carbonyls, $\alpha$-aminoadipic and $\gamma$-glutamic semialdehydes: Investigation of the formation mechanism and chemical nature in vitro and in vivo. Chem Res Toxicol 19:1059-1065. https://doi.org/10.1021/tx060026p

Akagawa M, Suyama K, Uchida K (2009) Fluorescent detection of $\alpha$-aminoadipic and $\gamma$-glutamic semialdehydes in oxidized proteins. Free Radic Biol Med 46:701-706. https://doi.org/10. 1016/j.freeradbiomed.2008.12.014

Alomari E, Bruno S, Ronda L et al (2018) Protein carbonylation detection methods: a comparison. Data Brief 19:2215-2220. https:// doi.org/10.1016/j.dib.2018.06.088

Arcanjo NMO, Luna C, Madruga MS, Estévez M (2018) Antioxidant and pro-oxidant actions of resveratrol on human serum albumin in the presence of toxic diabetes metabolites: glyoxal and methylglyoxal. Biochim Biophys Acta 1862:1938-1947. https://doi.org/ 10.1016/j.bbagen.2018.06.007

Armenteros M, Morcuende D, Ventanas J, Estévez M (2016) The application of natural antioxidants via brine injection protects Iberian cooked hams against lipid and protein oxidation. Meat Sci 116:253-259. https://doi.org/10.1016/j.meatsci.2016.02.027

Augustyniak E, Adam A, Wojdyla K et al (2015) Validation of protein carbonyl measurement: a multi-centre study. Redox Biol 4:149157. https://doi.org/10.1016/j.redox.2014.12.014

Bao Y, Boeren S, Ertbjerg P (2018) Myofibrillar protein oxidation affects filament charges, aggregation and water-holding. Meat Sci 135:102-108. https://doi.org/10.1016/j.meatsci.2017.09.011

Baraibar MA, Friguet B (2012) Chapter 7-changes of the proteasomal system during the aging process. In: Grune TBT-P in MB, Science $\mathrm{T}$ (ed) The Proteasomal system in aging and disease. Academic Press, Cambridge, pp 249-275

Bayarsaikhan G, Avan AN, Çekiç SD, Apak R (2019) Use of modified CUPRAC and dinitrophenylhydrazine colorimetric methods for simultaneous measurement of oxidative protein damage and antioxidant defense against oxidation. Talanta 204:613-625. https:// doi.org/10.1016/j.talanta.2019.06.049

Berlett BS, Stadtman ER (1997) Protein oxidation in aging, disease, and oxidative stress. J Biol Chem 272:20313-20316. https://doi. org/10.1074/jbc.272.33.20313

Bitalebi S, Nikoo M, Rahmanifarah K et al (2019) Effect of apple peel extract as natural antioxidant on lipid and protein oxidation of rainbow trout (Oncorhynchus mykiss) mince. Int Aquat Res 11:135-146. https://doi.org/10.1007/s40071-019-0224-y

Carvalho LM, Delgado J, Madruga MS, Estévez M (2021) Pinpointing oxidative stress behind the white striping myopathy: depletion of antioxidant defenses, accretion of oxidized proteins and impaired proteostasis. J Sci Food Agric 101:1364-1371. https://doi.org/ 10.1002/jsfa. 10747

Chen Z, Leinisch F, Greco I et al (2019) Characterisation and quantification of protein oxidative modifications and amino acid racemisation in powdered infant milk formula. Free Radic Res 53:68-81. https://doi.org/10.1080/10715762.2018.1554250

Cheng J, Tang D, Yang H et al (2021a) The dose-dependent effects of polyphenols and malondialdehyde on the emulsifying and gel properties of myofibrillar protein-mulberry polyphenol complex.
Food Chem 360:130005. https://doi.org/10.1016/j.foodchem. 2021.130005

Cheng Y, Chi Y, Geng X, Chi Y (2021b) Effect of 2,2'-azobis(2-amidinopropane) dihydrochloride (AAPH) induced oxidation on the physicochemical properties, in vitro digestibility, and nutritional value of egg white protein. Lwt 143:111103. https://doi.org/10. 1016/j.lwt.2021.111103

Climent I, Tsai L, Levine RL (1989) Derivatization of $\gamma$-glutamyl semialdehyde residues in oxidized proteins by fluoresceinamine. Anal Biochem 182:226-232. https://doi.org/10.1016/0003-2697(89) 90584-8

Colombo G, Clerici M, Garavaglia ME et al (2016) A step-by-step protocol for assaying protein carbonylation in biological samples. J Chromatogr B 1019:178-190. https://doi.org/10.1016/j.jchro mb.2015.11.052

Curtis JM, Hahn WS, Long EK et al (2012) Protein carbonylation and metabolic control systems. Trends Endocrinol Metab 23:399406. https://doi.org/10.1016/j.tem.2012.05.008

Davies MJ (2016) Protein oxidation and peroxidation. Biochem J 473:805-825. https://doi.org/10.1042/BJ20151227

de Santana Neto DC, Cordeiro ÂMTM, Meireles BRLA et al (2021) Inhibition of protein and lipid oxidation in ready-to-eat chicken patties by a spondias mombin L. Bagasse Phenolic-Rich Extract. Foods 10:1338. https://doi.org/10.3390/foods10061 338

Díaz-Velasco S, González A, Peña FJ, Estévez M (2020) Noxious effects of selected food-occurring oxidized amino acids on differentiated CACO-2 intestinal human cells. Food Chem Toxicol 144:1-8. https://doi.org/10.1016/j.fct.2020.111650

Driessen MD, Mues S, Vennemann A et al (2015) Proteomic analysis of protein carbonylation: a useful tool to unravel nanoparticle toxicity mechanisms. Part Fibre Toxicol 12:1-18. https://doi.org/ 10.1186/s12989-015-0108-2

Duque-Estrada P, Berton-Carabin CC, Nieuwkoop M et al (2019) Protein oxidation and in vitro gastric digestion of processed soybased matrices. J Agric Food Chem 67:9591-9600. https://doi. org/10.1021/acs.jafc.9b02423

Estaras M, Ameur FZ, Estévez M et al (2020) The lysine derivative aminoadipic acid, a biomarker of protein oxidation and diabetesrisk, induces production of reactive oxygen species and impairs trypsin secretion in mouse pancreatic acinar cells. Food Chem Toxicol 145:111594. https://doi.org/10.1016/j.fct.2020.111594

Esterbauer H (1993) Cytotoxicity and genotoxicity of lipid-oxidation products. Am J Clin Nutr 57:779S-786S. https://doi.org/10.1093/ ajen/57.5.779S

Estevez M, Morcuende D, Ventanas S (2008) Determination of oxidation. In: Mollet LML, Toldrá F (eds) Handbook of processed meat and poultry analysis. CRC Press, Boca Raton, pp 141-162

Estévez M (2011) Protein carbonyls in meat systems: a review. Meat Sci 89:259-279. https://doi.org/10.1016/j.meatsci.2011.04.025

Estévez M (2021) Critical overview of the use of plant antioxidants in the meat industry: opportunities, innovative applications and future perspectives. Meat Sci 181:108610. https://doi.org/10. 1016/j.meatsci.2021.108610

Estévez M, Luna C (2017) Dietary protein oxidation: a Silent threat to human health? Crit Rev Food Sci Nutr 57:3781-3793. https:// doi.org/10.1080/10408398.2016.1165182

Estévez M, Xiong Y (2019) Intake of oxidized proteins and amino acids and causative oxidative stress and disease: recent scientific evidences and hypotheses. J Food Sci 84:387-396. https://doi. org/10.1111/1750-3841.14460

Estévez M, Ollilainen V, Heinonen M (2009) Analysis of protein oxidation markers $\alpha$-Aminoadipic and $\gamma$-Glutamic semialdehydes in food proteins using liquid chromatography (LC)-Electrospray ionization (ESI)-Multistage tandem mass spectrometry (MS). J 
Agric Food Chem 57:3901-3910. https://doi.org/10.1021/jf804 $017 \mathrm{p}$

Estévez M, Padilla P, Carvalho L et al (2019) Malondialdehyde interferes with the formation and detection of primary carbonyls in oxidized proteins. Redox Biol 26:101277. https://doi.org/10. 1016/j.redox.2019.101277

Estévez M, Geraert PA, Liu R et al (2020) Sulphur amino acids, muscle redox status and meat quality: more than building blocks Invited review. Meat Sci 163:108087. https://doi.org/10.1016/j. meatsci.2020.108087

Estévez M, Li Z, Soladoye OP, Van-Hecke T (2017) Chapter two health risks of food oxidation. In: Toldrá $\mathrm{F}$ (ed) Advances in Food and Nutrition Research. Academic Press, Cambridge, Massachusetts, USA, pp 45-81

Fedorova M, Bollineni RC, Hoffmann R (2014) Protein carbonylation as a major hallmark of oxidative damage: update of analytical strategies. Mass Spectrom Rev 33:79-97. https://doi.org/10. $1002 /$ mas. 21381

Feng J, Berton-Carabin CC, Ataç Mogol B et al (2021) Glycation of soy proteins leads to a range of fractions with various supramolecular assemblies and surface activities. Food Chem 343:128556. https://doi.org/10.1016/j.foodchem.2020.128556

Ferreira VCS, Morcuende D, Madruga MS et al (2018) Role of protein oxidation in the nutritional loss and texture changes in ready-toeat chicken patties. Int J Food Sci Technol 53:1518-1526. https:// doi.org/10.1111/ijfs.13733

Flinders B, Morrell J, Marshall PS et al (2015) The use of hydrazinebased derivatization reagents for improved sensitivity and detection of carbonyl containing compounds using MALDI-MSI. Anal Bioanal Chem 407:2085-2094. https://doi.org/10.1007/ s00216-014-8223-8

Frame CA, Huff-Lonergan EJ, Rossoni Serao MC (2020) Impact of storage conditions on protein oxidation of rendered by-product meals. Transl Anim Sci 4:1-9. https://doi.org/10.1093/tas/txaa2 05

Frohnert BI, Bernlohr DA (2013) Protein carbonylation, mitochondrial dysfunction, and insulin resistance. Adv Nutr 4:157-163. https:// doi.org/10.3945/an.112.003319

Ge Y, Lin S, Li B et al (2020) Oxidized pork induces oxidative stress and inflammation by altering gut microbiota in mice. Mol Nutr Food Res 64:1901012. https://doi.org/10.1002/mnfr.201901012

Ge Y, Li B, Yang Y et al (2021) Oxidized pork induces disorders of glucose metabolism in mice. Mol Nutr Food Res 65:2000859. https://doi.org/10.1002/mnfr.202000859

Goethals S, Van Hecke T, Vossen E et al (2020) Commercial luncheon meat products and their in vitro gastrointestinal digests contain more protein carbonyl compounds but less lipid oxidation products compared to fresh pork. Food Res Int 136:109585. https:// doi.org/10.1016/j.foodres.2020.109585

Guo A, Xiong YL (2021) Myoprotein-phytophenol interaction: Implications for muscle food structure-forming properties. Compr Rev Food Sci Food Saf 20:2801-2824. https://doi.org/10.1111/15414337.12733

Gürbüz G, Heinonen M (2015) LC-MS investigations on interactions between isolated $\beta$-lactoglobulin peptides and lipid oxidation product malondialdehyde. Food Chem 175:300-305. https://doi. org/10.1016/j.foodchem.2014.11.154

Hawkins CL, Davies MJ (2019) Detection, identification, and quantification of oxidative protein modifications. J Biol Chem 294:19683-19708. https://doi.org/10.1074/jbc.REV119.006217

Hecker M, Wagner AH (2018) Role of protein carbonylation in diabetes. J Inherit Metab Dis 41:29-38. https://doi.org/10.1007/ s10545-017-0104-9
Hellwig M (2020) Analysis of protein oxidation in food and feed products. J Agric Food Chem 68:12870-12885. https://doi.org/10. 1021/acs.jafc.0c00711

Hernández-López SH, Rodríguez-Carpena JG, Lemus-Flores C et al (2016) Avocado waste for finishing pigs: Impact on muscle composition and oxidative stability during chilled storage. Meat Sci 116:186-192. https://doi.org/10.1016/j.meatsci.2016.02.018

Jung T, Grune T (2008) The proteasome and its role in the degradation of oxidized proteins. IUBMB Life 60:743-752. https://doi.org/ 10.1002/iub. 114

Kalaitsidis K, Sidiropoulou E, Tsiftsoglou O et al (2021) Effects of cornus and its mixture with oregano and thyme essential oils on dairy sheep performance and milk, yoghurt and cheese quality under heat stress. Animals 11:1063. https://doi.org/10.3390/ ani11041063

Kehm R, Baldensperger T, Raupbach J, Höhn A (2021) Protein oxidation-formation mechanisms, detection and relevance as biomarkers in human diseases. Redox Biol 42:101901. https://doi. org/10.1016/j.redox.2021.101901

Keller J, Chevolleau S, Noguer-Meireles MH et al (2020) Heme-ironinduced production of 4-hydroxynonenal in intestinal lumen may have extra-intestinal consequences through protein-adduct formation. Antioxidants (basel) 9(12):1293. https://doi.org/10. 3390/antiox9121293

Lahmar A, Morcuende D, Andrade MJ et al (2018) Prolonging shelf life of lamb cutlets packed under high-oxygen modified atmosphere by spraying essential oils from North-African plants. Meat Sci 139:56-64. https://doi.org/10.1016/j.meatsci.2018.01.015

Lapolla A, Flamini R, Vedova AD et al (2003) Glyoxal and methylglyoxal levels in diabetic patients: quantitative determination by a new GC/MS method. Clin Chem Lab Med 41:1166-1173. https://doi.org/10.1515/CCLM.2003.180

Lavado G, Higuero N, León-Camacho M, Cava R (2021) Formation of lipid and protein oxidation products during in vitro gastrointestinal digestion of dry-cured loins with different contents of nitrate/nitrite added. Foods 10:1748. https://doi.org/10.3390/ foods 10081748

Lee HJ, Jang HB, Kim WH et al (2019) 2-Aminoadipic acid (2-AAA) as a potential biomarker for insulin resistance in childhood obesity. Sci Rep 9:1-10. https://doi.org/10.1038/s41598-019-49578-z

Lefaki M, Papaevgeniou N, Chondrogianni N (2017) Redox regulation of proteasome function. Redox Biol 13:452-458. https://doi.org/ 10.1016/j.redox.2017.07.005

Levine RL (2002) Carbonyl modified proteins in cellular regulation, aging, and disease. Free Radic Biol Med 32:790-796. https://doi. org/10.1016/S0891-5849(02)00765-7

Li ZL, Mo L, Le G, Shi Y (2014) Oxidized casein impairs antioxidant defense system and induces hepatic and renal injury in mice. Food Chem Toxicol 64:86-93. https://doi.org/10.1016/j.fct.2013. 10.039

Li B, Mo L, Yang Y et al (2019) Processing milk causes the formation of protein oxidation products which impair spatial learning and memory in rats. RSC Adv 9:22161-22175. https://doi.org/10. 1039/c9ra03223a

Li F, Wu X, Wu W (2021a) Effects of oxidative modification by malondialdehyde on the in vitro digestion properties of rice bran protein. J Cereal Sci 97:103158. https://doi.org/10.1016/j.jcs.2020. 103158

Li YY, Yaylayan V, Palin M-F et al (2021b) Protective effects of dietary carnosine during in-vitro digestion of pork differing in fat content and cooking conditions. J Food Biochem 45:e13624. https://doi. org/10.1111/jfbc. 13624

Lin HM, Qi XE, Shui SS et al (2021) Label-free proteomic analysis revealed the mechanisms of protein oxidation induced by hydroxyl radicals in whiteleg shrimp (Litopenaeus vannamei) 
muscle. Food Funct 12:4337-4348. https://doi.org/10.1039/d1fo0 0380a

Luna C, Estévez M (2018) Oxidative damage to food and human serum proteins: radical-mediated oxidation vs. glyco-oxidation. Food Chem 267:111-118. https://doi.org/10.1016/j.foodchem.2017. 06.154

Luna C, Estévez M (2019) CEFormation of allysine in $\beta$-lactoglobulin and myofibrillar proteins by glyoxal and methylglyoxal: impact on water-holding capacity and in vitro digestibility. Food Chem 271:87-93. https://doi.org/10.1016/j.foodchem.2018.07.167

Luna C, Arjona A, Dueñas C, Estevez M (2021) Allysine and $\alpha$-aminoadipic acid as markers of the glyco-oxidative damage to human serum albumin under pathological glucose concentrations. Antioxidants 10:1-14. https://doi.org/10.3390/antiox 1003 0474

Lund MN (2021) Reactions of plant polyphenols in foods: Impact of molecular structure. Trends Food Sci Technol 112:241-251. https://doi.org/10.1016/j.tifs.2021.03.056

Ma J, Wang X, Li Q et al (2021) Oxidation of myofibrillar protein and crosslinking behavior during processing of traditional airdried yak (Bos grunniens) meat in relation to digestibility. Lwt 142:110984. https://doi.org/10.1016/j.lwt.2021.110984

Maisonneuve E, Ducret A, Khoueiry P et al (2009) Rules governing selective protein carbonylation. PLoS One 4:e7269. https://doi. org/10.1371/journal.pone.0007269

Malheiros JM (2019) Influence of oxidative damage to proteins on meat tenderness using a proteomics approach. Meat Sci 148:64-71. https://doi.org/10.1016/j.meatsci.2018.08.016

Mello CF, Sultana R, Piroddi M, Cai J, Pierce WMJ, Klein B, Butterfield DA (2007) Acrolein induces selective protein carbonylation in synaptosomes. Neuroscience 147(3):674-679. https://doi.org/ 10.1016/j.neuroscience.2007.04.003

Meyer B, Baum F, Vollmer G, Pischetsrieder M (2012) Distribution of protein oxidation products in the proteome of thermally processed milk. J Agric Food Chem 60:7306-7311. https://doi.org/ 10.1021/jf301666r

Mitra B, Lametsch R, Akcan T, Ruiz-Carrascal J (2018) Pork proteins oxidative modifications under the influence of varied time-temperature thermal treatments: a chemical and redox proteomics assessment. Meat Sci 140:134-144. https://doi.org/10.1016/j. meatsci.2018.03.011

Morzel M, Gatellier P, Sayd T et al (2006) Chemical oxidation decreases proteolytic susceptibility of skeletal muscle myofibrillar proteins. Meat Sci 73:536-543. https://doi.org/10.1016/j. meatsci.2006.02.005

Nieva-Echevarría B, Goicoechea E, Guillén MD (2020) Food lipid oxidation under gastrointestinal digestion conditions: a review. Crit Rev Food Sci Nutr 60:461-478. https://doi.org/10.1080/10408 398.2018.1538931

Niu X, Wang X, Han Y et al (2019) Influence of malondialdehydeinduced modifications on physicochemical and digestibility characteristics of whey protein isolate. J Food Biochem 43:1-9. https://doi.org/10.1111/jfbc. 13041

Oliver CN, Ahn BW, Moerman EJ et al (1987) Age-related changes in oxidized proteins. J Biol Chem 262:5488-5491. https://doi.org/ 10.1016/s0021-9258(18)45598-6

Öztürk-Kerimoğlu B, Nacak B, Özyurt VH, Serdaroğlu M (2019) Protein oxidation and in vitro digestibility of heat-treated fermented sausages: How do they change with the effect of lipid formulation during processing? J Food Biochem 43:e13007. https://doi.org/ $10.1111 / j \mathrm{fbc} .13007$

Özyurt H, Luna C, Estévez M (2016) Redox chemistry of the molecular interactions between tea catechins and human serum proteins under simulated hyperglycemic conditions. Food Funct 7:13901400. https://doi.org/10.1039/c5fo01525a
Requena JR, Chao CC, Levine RL, Stadtman ER (2001) Glutamic and aminoadipic semialdehydes are the main carbonyl products of metal-catalyzed oxidation of proteins. Proc Natl Acad Sci USA 98:69-74. https://doi.org/10.1073/pnas.98.1.69

Roldan M, Antequera T, Armenteros M, Ruiz J (2014) Effect of different temperature-time combinations on lipid and protein oxidation of sous-vide cooked lamb loins. Food Chem 149:129-136. https://doi.org/10.1016/j.foodchem.2013.10.079

Rowe LJ, Maddock KR, Lonergan SM, Huff-Lonergan E (2004) Influence of early postmortem protein oxidation on beef quality. J Anim Sci 82:785-793. https://doi.org/10.1093/ansci/82.3.785

Ruvalcaba-Márquez JC, Álvarez-Ruíz P, Zenteno-Savín T et al (2021) Performance, immune response, and oxidative stress parameters of Litopenaeus vannamei fed diets containing varying carbohydrate/protein, lipid/protein, and energy/protein ratios. Aquac Rep 21:100771. https://doi.org/10.1016/j.aqrep.2021.100771

Rysman T, Van Hecke T, Van Poucke C et al (2016) Protein oxidation and proteolysis during storage and in vitro digestion of pork and beef patties. Food Chem 209:177-184. https://doi.org/10.1016/j. foodchem.2016.04.027

Sante-Lhoutellier V, Aubry L, Gatellier P (2007) Effect of oxidation on in vitro digestibility of skeletal muscle myofibrillar proteins. J Agric Food Chem 55:5343-5348. https://doi.org/10.1021/jf070 $252 \mathrm{k}$

Sayd T, Chambon C, Laville E et al (2012) Early post-mortem sarcoplasmic proteome of porcine muscle related to lipid oxidation in aged and cooked meat. Food Chem 135:2238-2244. https://doi. org/10.1016/j.foodchem.2012.07.079

Semedo Tavares WP, Dong S, Yang Y et al (2018) Influence of cooking methods on protein modification and in vitro digestibility of hairtail (Thichiurus lepturus) fillets. Lwt 96:476-481. https://doi. org/10.1016/j.lwt.2018.06.006

Sharma A, Weber D, Raupbach J et al (2020) Advanced glycation end products and protein carbonyl levels in plasma reveal sex-specific differences in Parkinson's and Alzheimer's disease. Redox Biol 34:101546. https://doi.org/10.1016/j.redox.2020.101546

Sies H, Stahl W, Sevanian A (2005) Recent advances in nutritional sciences nutritional, dietary and postprandial. J Nutr 135:969-972

Silva FAP, Ferreira VCS, Madruga MS, Estévez M (2016) Effect of the cooking method (grilling, roasting, frying and sous-vide) on the oxidation of thiols, tryptophan, alkaline amino acids and protein cross-linking in jerky chicken. J Food Sci Technol 53:31373146. https://doi.org/10.1007/s13197-016-2287-8

Sobral MMC, Casal S, Faria MA et al (2020) Influence of culinary practices on protein and lipid oxidation of chicken meat burgers during cooking and in vitro gastrointestinal digestion. Food Chem Toxicol 141:111401. https://doi.org/10.1016/j.fct.2020. 111401

Soglia F, Petracci M, Ertbjerg P (2016) Novel DNPH-based method for determination of protein carbonylation in muscle and meat. Food Chem 197:670-675. https://doi.org/10.1016/j.foodchem. 2015.11.038

Soladoye OP, Juárez ML, Aalhus JL et al (2015) Protein oxidation in processed meat: mechanisms and potential implications on human health. Compr Rev Food Sci Food Saf 14:106-122. https://doi.org/10.1111/1541-4337.12127

Soladoye OP, Shand P, Dugan MER et al (2017) Influence of cooking methods and storage time on lipid and protein oxidation and heterocyclic aromatic amines production in bacon. Food Res Int 99:660-669. https://doi.org/10.1016/j.foodres.2017.06.029

Stadtman ER, Levine RL (2003) Free radical-mediated oxidation of free amino acids and amino acid residues in proteins. Amino Acids 25:207-218. https://doi.org/10.1007/s00726-003-0011-2

Steppeler C, Haugen J-E, Rødbotten R, Kirkhus B (2016) Formation of malondialdehyde, 4-hydroxynonenal, and 4-hydroxyhexenal 
during in vitro digestion of cooked beef, pork, chicken, and salmon. J Agric Food Chem 64:487-496. https://doi.org/10. 1021/acs.jafc.5b04201

Timm-Heinrich M, Eymard S, Baron CP et al (2013) Oxidative changes during ice storage of rainbow trout (Oncorhynchus mykiss) fed different ratios of marine and vegetable feed ingredients. Food Chem 136:1220-1230. https://doi.org/10.1016/j.foodchem.2012. 09.019

Trnková L, Dršata J, Boušová I (2015) Oxidation as an important factor of protein damage: implications for Maillard reaction. J Biosci 40:419-439. https://doi.org/10.1007/s12038-015-9523-7

Tsikas D (2017) Assessment of lipid peroxidation by measuring malondialdehyde (MDA) and relatives in biological samples: analytical and biological challenges. Anal Biochem 524:13-30. https://doi. org/10.1016/j.ab.2016.10.021

Utrera M, Estévez M (2012) Oxidation of myofibrillar proteins and impaired functionality: underlying mechanisms of the carbonylation pathway. J Agric Food Chem 60:8002-8011. https://doi.org/ $10.1021 / \mathrm{jf} 302111 \mathrm{j}$

Utrera M, Morcuende D, Rodríguez-Carpena JG, Estévez M (2011) Fluorescent HPLC for the detection of specific protein oxidation carbonyls $-\alpha$-aminoadipic and $\gamma$-glutamic semialdehydes-in meat systems. Meat Sci 89:500-506. https://doi.org/10.1016/j. meatsci.2011.05.017

Van Hecke T, Basso V, De Smet S (2018) Lipid and protein oxidation during in vitro gastrointestinal digestion of pork under Helicobacter pylori gastritis conditions. J Agric Food Chem 66:1300013010. https://doi.org/10.1021/acs.jafc.8b04335

Van Hecke T, Goethals S, Vossen E, De Smet S (2019) Long-Chain $n-3$ PUFA content and $n-6 / n-3$ PUFA ratio in mammal, poultry, and fish muscles largely explain differential protein and lipid oxidation profiles following in vitro gastrointestinal digestion. Mol Nutr Food Res 63:1-12. https://doi.org/10.1002/mnfr.20190 0404

Van Hecke T, Vossen E, Goethals S et al (2021) In vitro and in vivo digestion of red cured cooked meat: oxidation, intestinal microbiota and fecal metabolites. Food Res Int 142:110203. https:// doi.org/10.1016/j.foodres.2021.110203

Verrastro I, Pasha S, Jensen KT et al (2015) Mass spectrometry-based methods for identifying oxidized proteins in disease: advances and challenges. Biomolecules 5:378-411. https://doi.org/10. 3390/biom5020378

Villaverde A, Estévez M (2013) Carbonylation of myofibrillar proteins through the maillard pathway: effect of reducing sugars and reaction temperature. J Agric Food Chem 61:3140-3147. https://doi. org/10.1021/jf305451p

Villaverde A, Morcuende D, Estévez M (2014) Effect of curing agents on the oxidative and nitrosative damage to meat proteins during processing of fermented sausages. J Food Sci 79:C1331-C1342. https://doi.org/10.1111/1750-3841.12481

Wang TJ, Ngo D, Psychogios N et al (2013) 2-Aminoadipic acid is a biomarker for diabetes risk. J Clin Invest 123:4309-4317. https:// doi.org/10.1172/JCI64801

Wang Z, He Z, Gan X, Li H (2018) Interrelationship among ferrous myoglobin, lipid and protein oxidations in rabbit meat during refrigerated and superchilled storage. Meat Sci 146:131-139. https://doi.org/10.1016/j.meatsci.2018.08.006

Wang Y, Wang J, Wang S et al (2019a) Modification of glutenin and associated changes in digestibility due to methylglyoxal during heat processing. J Agric Food Chem 67:10734-10743. https:// doi.org/10.1021/acs.jafc.9b04337

Wang Z, He Z, Emara AM et al (2019b) Effects of malondialdehyde as a byproduct of lipid oxidation on protein oxidation in rabbit meat. Food Chem 288:405-412. https://doi.org/10.1016/j.foodc hem.2019.02.126

Wang Z, He Z, Zhang D et al (2021) The effect of linalool, limonene and sabinene on the thermal stability and structure of rabbit meat myofibrillar protein under malondialdehyde-induced oxidative stress. Lwt 148:111707. https://doi.org/10.1016/j.lwt.2021. 111707

Wong CM, Bansal G, Marcocci L, Suzuki YJ (2012) Proposed role of primary protein carbonylation in cell signaling. Redox Rep 17:90-94. https://doi.org/10.1179/1351000212Y.0000000007

Wong CM, Marcocci L, Das D et al (2013) Mechanism of protein decarbonylation. Free Radic Biol Med 65:1126-1133. https:// doi.org/10.1016/j.freeradbiomed.2013.09.005

Wu Y, Dong L, Wu Y et al (2021) Effect of methylglyoxal on the alteration in structure and digestibility of $\alpha$-lactalbumin, and the formation of advanced glycation end products under simulated thermal processing. Food Sci Nutr 9:2299-2307. https://doi.org/ $10.1002 / \mathrm{fsn} 3.2211$

Xiong Y (2000) Protein oxidation and implications for muscle food quality. In: Decker E, Faustman C, López-Bote CJ (eds) Antioxidants in muscle foods: nutritional strategies to improve quality. Jon Wiley and Sons, Hoboken, pp 85-111 (ref. 63)

Xiong YL, Guo A (2021) Animal and plant protein oxidation: chemical and functional property significance. Foods 10:40. https://doi. org/10.3390/foods 10010040

Xu J, Shi GP (2014) Vascular wall extracellular matrix proteins and vascular diseases. Biochim Biophys Acta 1842:2106-2119. https://doi.org/10.1016/j.bbadis.2014.07.008

Yu D, Zhao Y, Li T et al (2018) Effect of electrochemical modification on the structural characteristics and emulsion storage stability of soy protein isolate. Process Biochem 75:166-172. https://doi. org/10.1016/j.procbio.2018.10.001

Zhang X, Lu P, Xue W et al (2017) An evaluation of heat on protein oxidation of soy protein isolate or soy protein isolate mixed with soybean oil in vitro and its consequences on redox status of broilers at early age. Asian-Australas J Anim Sci 30:1135-1142. https://doi.org/10.5713/ajas.16.0683

Zhang D, Li H, Wang Z et al (2020) Effects of in vitro oxidation on myofibrillar protein charge, aggregation, and structural characteristics. Food Chem 332:127396. https://doi.org/10.1016/j.foodc hem.2020.127396

Zhang L, Li Q, Hong H, Luo Y (2021) Tracking structural modifications and oxidative status of myofibrillar proteins from silver carp (Hypophthalmichthys molitrix) fillets treated by different stunning methods and in vitro oxidizing conditions. Food Chem 365:130510. https://doi.org/10.1016/j.foodchem.2021.130510

Zhao Y, Kong H, Zhang X et al (2019) The effect of Perilla (Perilla frutescens) leaf extracts on the quality of surimi fish balls. Food Sci Nutr 7:2083-2090. https://doi.org/10.1002/fsn3.1049

Zhao X, Xu X, Zhou G (2021) Covalent chemical modification of myofibrillar proteins to improve their gelation properties: a systematic review. Compr Rev Food Sci Food Saf 20:924-959. https://doi.org/10.1111/1541-4337.12684

Zhou F, Sun W, Zhao M (2015) Controlled formation of emulsion gels stabilized by salted myofibrillar protein under malondialdehyde (MDA)-induced oxidative stress. J Agric Food Chem 63:37663777. https://doi.org/10.1021/jf505916f

Publisher's Note Springer Nature remains neutral with regard to jurisdictional claims in published maps and institutional affiliations. 